Terbit online pada laman web jurnal : http://e-journal.sastra-unes.com/index.php/JIPS

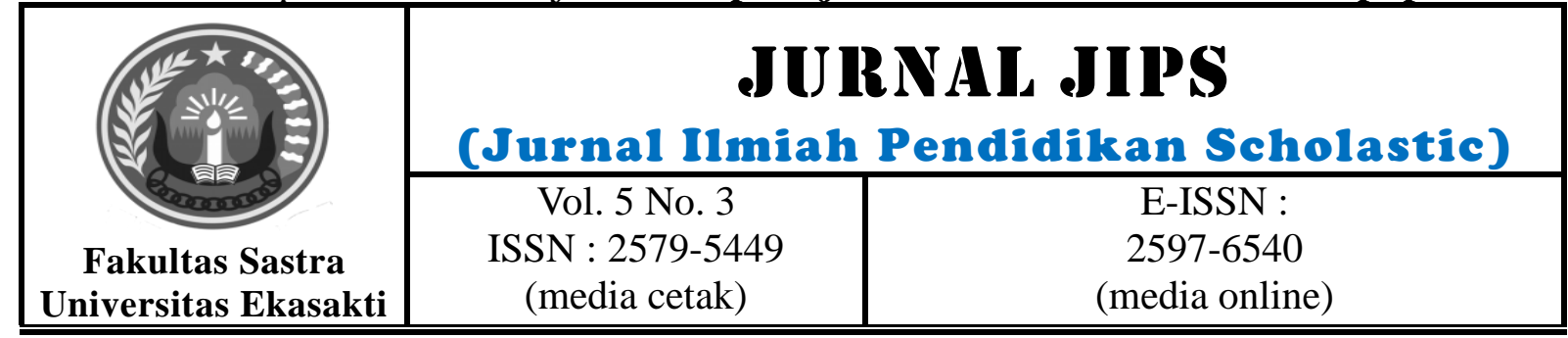

\title{
STRATEGI MENINGKATKAN KEMAMPUAN SOFT SKILL MAHASISWA STIE KBP DALAM BERWIRAUSAHA
}

\author{
Dewirahmadanirwati \\ STIE KBP Padang, dewirahmadanirwati9@gmail.com
}

\begin{abstract}
Abstrak
Salah satu usaha untuk mengurangi tingkat pengangguran terdidik di Indonesia adalah dengan menciptakan lulusan-lulusan yang tidak hanya memiliki orientasi sebagai job seeker, namun juga perlu untuk menjadi job maker atau disebut dengan berwirausaha. Seiring dengan perkembangan ilmu pengetahuan dan teknologi, kemampuan untuk menjadi seorang wirausaha tidak hanya ditentukan dengan memahami pengetahuan kewirausahaan saja, tatapi juga harus memiliki softskill yang baik untuk menjadi seorang entrepreneur atau wirausaha. Dengan kemampuan softskill yang baik, maka lulusan akan dapat bersaing menjadi seorang entrepreneur baik di dalam maupun di luar negeri. Untuk mewujudkan hal tersebut praktisi pendidikan perlu memperhatikan hal-hal yang berhubungan dengan pengembangan softskill dikalangan peserta didik. Penelitian ini bertujuan untuk meningkatkan Kemampuan softskill dikalangan mahasiswa STIE KBP dalam berwirausaha. Untuk meningkatkan softskill dikalangan mahasiswa ada beberapa strategi yang perlu dilakukan, diantaranya; melatih mahasiswa untuk berpikir secara analisis, melatih mahasiswa menyelesaikan masalah dengan baik, berkomunikasidengan baik, melatih kemampuan bernegosiasi,melatih jiwa kepemimpinan dilingkungan mahasiswa, serta menerapkan rasa tanggung jawab dan komitmen yang tinggi dalam mengembangkan usaha.
\end{abstract}

Kata Kunci: Strategi, Meningkatkan, Kemampuan, Softskill, Berwirausaha, Mahasiswa

(C) 2021Jurnal JIPS

\section{INTRODUCTION}

Wirausaha adalah orang yang mampu menciptakan bisnis baru, dan orang yang biasanya lansung berhadapan dengan resiko dan ketidakpastian dalam mencapai keberhasilan. Seorang wirausaha harus mampu mengidentifikasi berbagai kesempatan, dan mencurahkan seluruh sumber daya yang ia miliki untuk mengubah kesempatan menjadi sesuatu yang menguntungkan. Pilihan menjadi wirausaha merupakan salah satu alternative yang paling menjanjikan untuk kehidupan yang akan datang, apalagi bagi generasi muda atau generasi milineal saat ini, mengingat sekarang tingginya tingkat angka pengangguran terdidik. Untuk mewujudkan hal tersebut, pelatihan kewirausahaan bagi generasi muda harus terus menerus dilakukan oleh siapa pun yang peduli tehadap, kesejahteraan masyarakat untuk melahirkan sebanyak-banyaknya calon wirausaha baru, dalam rangka menguragi angka pengangguran terdidik dan menigkatkan pertumbuhan ekonomi bangsa Indonesia.

Salah satu upaya untuk mengurangi tingkat pengangguran terdidik di Indonesia saat 
ini adalah dengan menciptakan lulusan- lulusan yang tidak hanya memiliki orientasi sebagai job seeker namun juga harus mampu untuk menjadi job maker atau yang disebut dengan wirausaha. Banyak kalangan terdidik di Indonesia berusaha untuk menghindari menjadi seorang wirausaha, hampir $80 \%$ dari mereka memilih untuk mencari kerja diperkantoran atau menjadi PNS. Berdasarkan hasil riset yang dilakukan terhadap mahasiswa STIE KBP Jurusan Manajemen hampir $80 \%$ mereka mengatakan akan menjcari kerja sebagai PNS, atau bekerja di suatu perusahaan, setelah mereka lulus menjadi seorang sarjana. Hanya $20 \%$ yang menjawab kalau mereka ingin berwirausaha. Hal ini tentu menjadi suatu permasalahan yang perlu dicarikan solusinya, mengingat sekarang ini tingginya angka penggangguran terdidik, apalagi Indonesia saat ini mengalami krisis akibat pandemi covid19 yang belum bisa diatasi secara maksimal. Banyaknya perusahaan yang mengalami kebangkrutan, dan tingginya angka pengangguran akibat pandemi, ini menjadi suatu permasalahan bagi perguruan tinggi untuk menyiapkan lulusan yang berkualitas. Salah satu cara yang paling dianggap efektif untuk mengurangi angka pengangguran adalah membekali mahasiswa untuk menjadi seorang wirausaha. Untuk merobah pola pikir mahasiswa menjadi seorang wirausaha tidaklah semudah membalik telapak tangan, tetapi perlu proses yang harus dilalui agar mereka tertarik untuk berwirausaha. Salah satu cara yang harus dilakukan adalah meningkatkan softskill mereka dalam berwirausaha.

Softskill adalah kepribadian atau atribut personal, serta kemampuan berkomunikasi yang dibutuhkan untuk sukses dalam sebuah pekerjaan. Softskill yang dimiliki oleh seseorang tergantung bagaimana dia berkomunikasi dengan orang disekitarnya. Softskill tidak bisa diperoleh dengan cara belajar, tetapi ditentukan dengan lebih banyak berintegrasi dengan orang lain, serta melatih kepekaan terhadap lingkungan. Softskill merupakan kemampuan dalam berkomunikasi yang merupakan sifat bawaan dan tidak dipelajari secara formal. Dalam berwirausaha softskill merupakan aspek penting yang sangat menentukan kesuksesan seseorang untuk menjadi wirausaha. Penelitian ini sebelumnya dilakukan oleh Utomo (2010) yang menjelaskan tentang kemampuan softskill dalam berwirausaha. Utomo menjelaskan kemampuan softskill dan kemampuan atau keterampilan berhubungan dengan orang lain (people skills) hal yang perlu dimiliki oleh seorang wirausaha. Menurut Utomo (2010) dengan adanya kompetensi memungkinkan seseorang untuk bersaing dalam memasuki dunia kerja atau dunia usaha. Sementara Diandra (2019) menjelaskan bahwa pelaku usaha harus memahami dan mempraktekkan ilmu kewirausahaan dalam berbisnis dengan segala kemampuan dan persiapan mental. Seiring dengan pesatnya perkembangan teknologi saat ini, dan ketatnya persaingan dalam dunia bisnis, mengharuskan para lulusan perguruan tinggi untuk dapat bersaing secara kompetitif dalam menjadi seorang wirausaha, agar mereka bisa menjadi sukses dalam berwirausaha. Yang menjadi permasalahan saat ini belum maksimalnya usaha yang dilakukan oleh praktisi pendidikan untuk menumbuhkan mental, sikap, dan perilaku kewirausahaan dilingkungan peserta didik. Menurut Diandra (2019) Pendidikan kewirausahan, dan mental kewirausahaan dapat menciptakan nilai kompetitif dan daya saing bagi pelaku usaha. Kemampuan softskill berwirausaha dapat dipelajari, dibentuk, dan diajarkan pada diri seseorang khususnya dalam berwirausaha (Hadiyati, 2018).

\section{Pengertian Wirausaha}

Istilah kewirausahaan (Entrepreneur) pertama kali diperkenalkan pada awal abad ke-18 oleh ekonom Perancis, Richard Cantillon. Entrepreneur adalah "agen who buys means of production at certain prices in order to combine them". Secara etimologis wirausaha/ wiraswata berasal dari bahasa Sansekerta, yang terdiri dari tiga suku kata "wira"," swa" dan " sta". Wira berarti unggul, teladan, tangguh, berbudi luhur, berjiwa besar, berani, pahlawan, pionir, pendekar/pejuang kemajuan,memiliki keagungan watak. Swa berarti sendiri, dan sta berarti berdiri. Istilah kewirausahaan pada dasarnya berasa dari terjemahan entrepreneur, yang dalam bahasa Inggris dikenal dengan between taker atau go between, (Dharmawati, 2016). Sedangkan menurut INPRES No.4 Tahun 1995 tentang Gerakan Nasional Memasyarakatkan dan Membudidayakan Kewirausahaan adalah semangat, sikap, perilaku, dan kemampuan seseorang dalam menangani usaha dan/atau 
kegiatan yang mengarah pada upaya mencari, menciptakan, menetapkan cara kerja, teknologi dan produk baru dengan meningkatkan efesiensi dalam rangka memberikan pelayanan yang lebih baik dan/ atau memperoleh keuntungan yang lebih besar. Menurut Dan Steinhoff dan Jhon F. Burgess (1995) wirausaha adalah orang yang mengorganisir, mengelola, dan berani menanggung resiko untuk menciptakan usaha baru dan peluang berusaha. Zimmerer (1996) mengatakan kewirausahaan adalah suatu proses penerapan kreativitas dan inovasi dalam memecahkan persoalan dan menemukan peluang untuk memperbaiki kehidupan. Sedangkan menurut Dharmawati (2017) kewirausahaan merupakan sikap mental dan sifat jiwa yang selalu aktif dalam berusaha untuk memajukan karya baktinya dalam rangka upaya meningkatkan pendapatan di dalam kegiatan usahanya. Selain itu kewirausahaan adalah kemampuan kreatif dan inovatif yang dijadikan dasar,kiat, dan sumber daya untuk mencari peluang menuju sukses. Berdasarkan definisi di atas dapat disimpulkan bahwa kewirausahaan adalah kemampuan seseorang dalam menangani usaha, dengan segala resiko untuk menciptakan sesuatu usaha baru berdasarkan kreativitas dan inovasi dengan memberdayakan sumber daya yang ada untuk mencari peluang menuju sukses.

\section{Keuntungan dan Kerugian Berwirausaha}

Menurut Ilik (2010), terdapat keuntungan dan kerugian ketika seseorang memutuskan untuk menjadi seorang wirausaha. Keuntungan menjadi wirausaha adalah:

a. Otonomi maksudnya adalah seorang wirausaha memiliki kebebasan terhadap control bisnis yang mereka kelola.

b. Tantangan awal dan perasaan motif berprestasi. Maksudnya seorang wirausaha memiliki peluang untuk mengembangkan konsep usaha yang dapat menhasilkan keuntungan sangat memotivasi wirausaha.

c. Kontrol Finansial. Maksudnya seorang wirausaha bebas untuk mengontrol keuangan, dan merasa kekayaan sebagai milik sendiri.

d. Memiliki legitimasi moral yang kuat untuk mewujudkan kesejahteraan dan menciptakan kesempatan kerja.

Sedangkan kerugian dalam berwirausaha adalah:
a. Pengorbanan personal
b. Beban dan tanggung jawab
c. Kecilnya margin keuntungan dan kemungkinan gagal.

\section{Peningkatan Kemampuan Softskill Menurut Para Ahli}

Peningkatan kemampuan softskill sangat dibutuhkan jika menjadi seorang wirausaha, seperti; tanggung jawab, berjiwa social, manajemen diri, integritas, kejujuran, dan kemampuan interpersonal (berkomunikasi). Menurut Utomo (2010) softskill dalam berwirausaha yang perlu untuk dikembangkan adalah kemampuan interpersonal, seperti aktif berpartisipasi sebagai anggota tim, mendidik orang lain, melayani klien,melatih kepemimpinan, kemampuan bernegosiasi, hingga bekerja dengan pendekatan budaya. Kemampuan softskill tidak hanya dibutuhkan dalam dunia kerja namun sangat dibutuhkan dalam berwirausaha. Menurut Utomo kenapa jumlah pengusaha di Indonesia sampai saat ini masih sedikit, karena kurangnya kemampuan softskill yang dimiliki oleh pelaku usaha tersebut. Spitzberg (1987) mengasumsikan kemampuan interpersonal sebagai evaluasi dari tingkah laku yang berangkat dari pendekatan tradisional ke pendekatan asesmen. Pendekatan tradisional termanifestasi pada pengetahuan dan penampilan. Semakin pesatnya perkembangan ilmu pengetahuan dan teknologi dari revolusi 4.0 ke revolusi 5.0, kemampuan softskill menjadi hal utama yang paling diperhitungkan dalam berwirausaha. Walau pun berwirausaha atau berbisnis merupakan suatu hal yang sangat mengiurkan, tetapi seorang wirausaha harus mampu dan berani untuk mengambil resiko. Kuswara (2010) menjelaskan dalam penelitiannya bahwa lulusan perguruan tinggi dalam negeri memiliki nilai kompetisi yang kurang karean kurang percaya diri, kurang mampu berkomunikasi di depan umum, lambat beradaptasi, hingga kurang mampu menhadapi tekanan dalam masalah perkerjaan. Ketidak mampuan di bidang softskill ini menyebabkan lulusan dalam negeri kalah dalam berkompetisi di kancah internasional. Sedangkan Arifin (2013) dalam penelitiannya mengatakan softskill, khususnya interpersonal skills memiliki peran yang sangat penting terhadap kesuksesan seseorang. Dalam penelitiaannya dia menekankan pada dua kecerdasan yang diberikan

Jurnal JIPS (Jurnal Ilmiah Pendidikan Scholastic ) Vol. 5 No. 3 (2021) ISSN : 2579-5449

This work is licensed under a Creative Commons Attribution-NonCommercial 4.0 International License. 
dengan kemampuan mengembangkan kepribadian, yaitu kecerdasan interpersonal (interpersonal intelligence) dan kecerdasan intrapersonal (intrapersonal intelligence). Kecerdasan interpersonal terfokus pada perasaan, motivasi, watak, dan temperamental seseorang. Sedangkan kecerdasan intrapersonal adalah peka terhadap lingkungan dan isyarat gerak tubuh serta kemampuan dlam membangun relasi dan berkomunikasi dengan orang lain. Sarjanti (2010) dalam penelitiannya menjelaskan bahwa kemampuan softskill berkaitan dengan kecakapan non jasmani yang sangat penting dalam meraih keuksesan. Kemampuan tersebut dapat dikembangkan dalam bentuk keberanian yang didasari oleh kebenaran, kepedulian terhadap sesama, tolong menolong, jujur, disiplin,komitmen, motivasi, kritis, kreatif, komunikatif, dan tekun. Perilaku seseorang dalam berwirausaha sangat dipengaruhi oleh penguasaan kecerdasan softskillnya (Diandra, 2019).

\section{Pengertian Strategi}

\section{RESEARCH METHOD}

Penelitain ini menggunakan metode non riset, karena dalam penelitian ini peneliti hanya mengumpulkan informasi dalam beberapa sumber, seperti buku, jurnal, dan internet, serta informasi berupa pendapat yang dikemukakan oleh para pakar. Penelitian ini membahas kajian

\section{RESULTS AND DISCUSSION}

Kemampuan softskill merupakan kemampuan yang sangat penting dimiliki oleh seorang mahasiswa dalam berwirausaha. Softskill merupakan suatu bakat yang bisa dikembangkan secara pribadi. Keahlian ini berjalan seiring dengan kemampuan teknis atau hard skill. Kemampuan softskill yang harus dimiliki oleh seorang mahasiswa untuk membentuk atau meningkatkan jiwa entrepreneur dikalangan mahasiswa. Ada beberpa strategi yang perlu dilakukan dalam meningkatkan softskill dilingkungan mahasiswa STIE KBP, di antaranya adalah:

1. Melatih Untuk Berpikir Secara Analisis. Maksudnya untuk meningkatkan softskill dilingkungan mahasiswa dalam berwirausaha
Strategi adalah ilmu perencanaan dan penentuan arah operasi-operasi bisnis berskala besar, menggerakan semua sumber daya perusahaan yang dapat menguntungkan secara aktual dalam bisnis . Menurut David (2004), strategi adalah rencana yang disatukan, luas dan berintegrasi yang menghubungkan keunggulan strategis perusahaan dengan tantangan lingkungan, yang dirancang untuk memastikan bahwa tujuan utama dari perusahaan yang dapat dicapai melalui pelaksanaan yang tepat oleh organisasi. Strategi juga merupakan sejumlah tindakan yang terintegrasi dan terkoordinasi yang diambil untuk mendayagunakan kompetensi inti serta memperoleh keunggulan bersaing. Dari definisi di atas dapat disimpulkan bahwa strategi adalah suatu rencana yang ditujukan untuk mencapai suatu tujuan yang diinginkan. Inti dari strategi adalah bagaimana bertahan hidup dalam bersaing secara kompetitif, serta mampu mengenali kekuatan dan kelemahan pesaing.

tentang Strategi Meningkatkan Kemampuan Softskill Mahasiswa STIE KBP dalam Berwirausaha. Tinjauan dilakukan dari aspek literature, kemudian dianalis. Dalam penelitian ini pembahasan dijelaskan pada studi kepustakaan.

mereka harus dilatih untuk pintar dalam membaca situasi yang sedang terjadi, dan memprediksi apa yang akan terjadi didepan dalam berwirausaha.

2. Melatih Kemampuan dalam Menyelesaikan Masalah dengan Tepat.

Maksudnya dalam menghadapi suatu permasalahan dalam berwirausaha mereka harus mampu untuk memecahkan suatu permasahan dengan menggunakan SWOT analisis, agar semua keputusan yang akan diambil tidak mengalami kesalahan yang akan berdampak terhadap perkembangan organisasi. Kemampuan ini sangat berkaitan dengan kemampuan berpikir analisis.

Jurnal JIPS (Jurnal Ilmiah Pendidikan Scholastic ) Vol. 5 No. 3 (2021) ISSN : 2579-5449

This work is licensed under a Creative Commons Attribution-NonCommercial 4.0 International License. 


\section{Meningkatkan}

Berkomunikasi dengan Baik .

Maksudnya kemampuan berkomunikasi merupakan modal dasar yang harus dimiliki oleh seorang mahasiswa dalam berwirausaha. Kemampuan berkomunikasi adalah sarana yang sangat penting untuk mencapai suatu kesuksesan dalam berwirausaha. Karena jaringan bisnis tertentu hanya bisa dilakukan melalui komunikasi, apalagi saat revolusi indutri 5.0 saat ini, kemampuan berkomunikasi sangat memegang peran penting. Jika seorang wirausaha tidak memiliki keahlian dalam berkomunikasi, maka mereka tidak akan sukses dalam mencapai tujuannya dalam berbisnis.

4. Melatih Kemampuan Bernegosiasi.

Bernegosiasi dalam bisnis sangat diperlukan agar dapat mencapai tujuan yang diinginkan. Seorang wirausaha harus memiliki kemampuan bernegosiasi, maksudnya harus pandai bernegosiasi, agar dapat dengan mudah untuk mencapai kesepakatan bersama untuk mendapatkan suatu keuntungan.

5. Memberikan Pelatihan Manajemen Waktu.

Seorang mahasiswa dalam berwirausaha harus pandai dalam manajemen waktu. Meskipun memiliki flesibelitas waktu, pelaku wirausaha harus pandai-pandai dalam mengatur waktunya. Karena sorang pengusaha tidak selamanya berada di kantor, tetapi kadang-kadang mereka berasa di luar untuk bertemu dengan klien atau calon kliennya, atau mengurus hal-hal yang lain yang berhubungan dengan bisnisnya. Oleh karena itu seorang wirausaha harus memiliki softskill manajemen waktu yang baik, sehingga dapat memprioritaskan kegiatan yang dianggap penting terlebih dahulu.

6. Meningkatkan Jiwa Kepemimpinan.

Maksudnya dalam berwirausaha jiwa kepemimpin sangat dibutuhkan. karena jika dalam kegiatan berwirausaha tidak ada pemimpin, maka kegiatan wirausaha itu akan hancur, karena tidak ada arah yang jelas dan tidak ada yang bisa untuk mengarahkan dan untuk mengambil keputusan dalam organiasi atau wirausaha tersebut. Jiwa kepemimpinan dalam berwirausaha akan tumbuh sejalan dengan proses yang ada serta pengakuan dari para anggota yang mereka pimpin.Jika ingin menjadi pelaku wirausaha maka mahasiswa harus dibekali dengan jiwa kepemimpinan yang baik, sehingga diharapkan kelak mereka mampu untuk menjadi seorang entrepreneur dan dapat menjalankan usaha mereka dengan baik dan sukses..

Menerapkan Rasa Tanggung jawab dan komitmen dalam mengembangkan usaha. Maksudnya rasa tanggung jawab dan komitmen yang tinggi merupakan softskill yang harus dimiliki oleh seorang pengusaha atau pelaku wirausaha. Sikap rasa tanggung jawab dan komitmen dalam berwirausaha dapat terlihat dari segi menepati janji, bertanggung jawab dan komitmen dalam melakukan kegiatan dan realisasinya, bertanggung jawab komitmen dalam menjaga kontrak, dan hubungan kerja, serta bertanggung jawab komitmen dalam mengembangkan usaha yang dijalani. Tanpa rasa tanggung jawab dan komitmen seorang wirausaha tidak akan bisa sukses dalam mencapai tujuan.

\section{CONCLUSION}

Strategi meningkatkan softskill dalam berwirausaha dilingkungan mahasiswa STIE KBP dapat dilakukan dengan berbagai cara, diantaranya; melatif mahasiswa untuk berpikir secara analisis, melatih menyelesaikan menyelesaikan masalah dengan tepat, meningkatkan kemampuan berkomunikasi dengan baik, melatih mahasiswa untuk dapat bernegosiasi dengan baik, memberikan pelatihan manajemen waktu, menumbuhkan jiwa kepemimpinan, serta menerapkan rasa tanggung jawab dan komitmen yang tinggi dalam mengembangkan usaha melalui praktek kewirausahaan. Softskill dikalangan mahasiswa dalam berwirausaha perlu untuk ditingkatkan, melalui praktek kewirausahaan. Karena kemampuan softskill merupakan hal sangat menentukan kesuksesan mahasiswa dalam berwirausaha, selain kemampuan hard skills. 


\section{Bibliography}

[1]Astamoen, P Moko. 2005. Entrepreneurship dalam Perspektif Kondisi Bangsa Indonesia. Jakarta: Alfabeta.

[2]David. 2004. Manajemen Strategi Konsep. Jakarta: Salemba Empat.

[3]Diandra. 2019. "Meningkatkan Kemampuan Softskill Dalam Berwirausaha". Dalam https:/ejournal.stiedewantara.ac.id/index. $\mathrm{php} / \mathrm{SNEB} /$ issue/view/46.Diunduh 10 Desember 2021.

[4]Dharmawati,D Made. 2017. Kewirausahaan. Depok: Raja Grafindo.

[5]Fandy, Tjiptono.2008. Strategi Pemasaran. Yogyakarta: Andika Offset.

[6]Hasan, R. (2018). Berani Ambil Resiko Jadi Kunci Pengusaha Muda Sukses.https://economy.okezone.com/rea d 2021/10/12/320/1985690/berani-ambilrisiko-jadi-kunci-pengu-saha-mudasukses, diakses 10 Desember 2021
(Pustaka berupa artikel dari situs Internet).

[7]Kuswara, H. 2010. "Strategi Sukses Mahasiswa Indonesia Meraih Karir Gumilang Dengan Softskill”. Jurnal Humaniora, Vol.10. No.1

[8]Rahmawati, Y. 2014. Manajemen Publik Relations Sebagai Alat Etika Komunikasi Dalam Bisnis Islam.Jurnal Filsafat dan Budaya Hukum. 15 November 2014.P.181-194. (Pustaka berupa artikel dalam majalah/jurnal ilmiah).

[9]Utomo, H. 2010 Kontribusi Softskill Dalam Menumbuhkan Jiwa Kewirausahaan, Among Makarti, Vol 3 No.5 Juli 2010.

[10]Zimmerer. W Thomas, Norman M. Scarborough. 1996. Entrepreneurship and New Venture Formation, Inc. hal 51. New Jersey : Prentice Hall International 